\title{
Rediscovery of Chirostylus dolichopus Ortmann, 1892 (Crustacea: Decapoda: Anomura: Chirostylidae) from its type locality, Boso Peninsula, Japan, with description of the colouration in life
}

\author{
Junji Okuno ${ }^{1 *}$ and Masayuki Osawa ${ }^{2}$
}

\begin{abstract}
Background: The chirostylid squat lobster, Chirostylus dolichopus Ortmann, 1892, was rediscovered from its type locality, Katsuyama (Boso Peninsula, Honshu, Japan) $\left(35^{\circ} 06.7^{\prime} \mathrm{N}, 139^{\circ} 48.8^{\prime} \mathrm{E}\right)$, since the holotype had been collected in 1880. The colouration in life of $\mathrm{C}$. dolichopus is reported for the first time on the basis of a recently captured topotypic specimen.

Results: Chirostylus dolichopus is characterized by the brilliant yellow ground colour and spot pattern on the meri of the ambulatory pereopods.

Conclusions: The colouration in life of C. dolichopus is diagnostic for species of Chirosty/us. The examination of the present specimen revealed that $C$. dolichopus is distinguishable from other shallow water congeners, such as $C$. ortmanni, C. sandyi, and C. stellaris, by the colouration as well as morphology.
\end{abstract}

Keywords: Crustacea, Chirostylidae, Chirostylus dolichopus, Topotypic specimen, Colouration, Japan

\section{Background}

Chirostylus Ortmann, 1892 is a small genus of the family Chirostylidae and contains seven species, all from the Indo-West Pacific (Baba et al., 2008; Baba, 2009): C. dolichopus Ortmann, 1892; C. micheleae Tirmizi \& Khan, 1979; C. novaecaledoniae Baba, 1991; C. ortmanni Miyake \& Baba, 1968; C. rostratus Osawa \& Nishikiori, 1998; C. sandyi Baba, 2009, and C. stellaris Osawa, 2007. The type species of the genus, $C$. dolichopus, was originally described from Kadsiyama (= Katsuyama), Boso Peninsula, Japan, and has hitherto been reported from wide but scatterred localities in the Indo-West Pacific (cf. Baba et al., 2008). Prior to the present study, no additonal specimens of the species have been recorded from the type locality since the German biologist, Dr.

\footnotetext{
* Correspondence: okuno@chiba-muse.or.jp

${ }^{1}$ Coastal Branch of Natural History Museum and Institute, 123 Yoshio,

Katsuura, Chiba 299-5242, Japan

Full list of author information is available at the end of the article
}

Ludwig H. P. Döderlein collected the holotype there in 1880. Moreover, the colouration in life is diagnostic for species of Chirostylus (see Baba, 2009), but was not recorded for the holotype of $C$. dolichopus. During a recent study on the shallow-water crustacean fauna of Boso Peninsula, we found the second specimen referable to $C$. dolichipus from Katsuyama. The present paper describes for the first time the colouration in life of $C$. dolichopus based on a topotypic material. The possible identities of specimens from other localities previously reported as C. dolichopus were briefly discussed.

\section{Methods}

$\mathrm{CL}$ indicates specimen size, and is measured along the dorsal midline from the posterior margin of the orbit to the posterior margin of the carapace. The specimen examined was collected with SCUBA equipment, and is deposited in the collection of $\mathrm{CMNH}$. 


\section{Results}

Taxonomic account

Order Decapoda Latreille, 1802

Infraorder Anomura MacLeay, 1838

Family Chirostylidae Ortmann, 1892

Genus Chirostylus Ortmann, 1892

Chirostylus dolichopus Ortmann, 1892

Figs. $1 \& 2$

\section{Synonymy}

Chirostylus dolichopus Ortmann, 1892: 246, figs. 2, 2b, c, e, i, o, z [type locality: Kadsiyama (= Katsuyama), Boso Peninsula, Japan, shallow water]; Miyake, 1960: 97, pl. 48, fig. 8; Miyake \& Baba, 1968: 381, figs. 1a, b, 2; Takeda, 1982: 49, fig. 147; Baba, 2005: 16 (part, see discussion), fig. 2; Baba et al., 2008: 14 (part, see discussion; not fig. 1A).

\section{Material examined}

CMNH-ZC 02495, 1 female (CL 5.5 mm), Uki-shima Islet, Katsuyama, Kyonan, Boso Peninsula (east side of Tokyo Bay), Honshu, Japan, 3506.7'N, 13948.8'E, 30 m, SCUBA, 14 July 2015, coll. J. Okuno.

\section{Distinguishing characters}

Rostral lobe rounded, unarmed (Fig. 1a). Gastric and cardiac regions unarmed. Branchial regions armed each with 1 spine near anterior extremity of each cervical groove (Fig. 1a). Third thoracic sternite with surface concave; anterior margin transverse, armed with 6 small spines (Fig. 1b). Abdominal somites with smooth dorsal surface. Ocular peduncle with feebly dilated cornea (Fig. 1a). Dactyli of second to fourth pereopods each with 6 (except for 7 in left fourth pereopod) corneous spines on flexor margin, penultimate spine distinctly stouter than ultimate spine (Fig. 1c).

\section{Colouration}

Ground colour of body and pereopods overall bright yellow (Fig. 2a, b). Dorsal surface of carapace (Fig. 2c) pale orange, with 3 main concentric $\mathrm{U}$ - to $\mathrm{V}$-shaped markings: outermost U-shaped, red with clear inner and outer margins, approximately following carapace outline; next white with narrow, clear margins, apex tightly rounded, approximately enclosing protogastric region; innermost whiteclear with red margins, acutely triangular, anterior apex slightly exceeding cervical groove. Pterygostomian flap with alternating white and orange-red longitudinal lines. Abdominal tergites (Fig. 2c) transparent; anterior margin and midline each with orange line. Ocular peduncles each with thick red line dorsomesially. Cheliped (first pereopod) (Fig. 2a, b) with white and red longitudinal lines dorsolaterally. Second to fourth pereopods (Fig. 2a, b) each with red longitudinal line dorsally except for distal part of propodus, this part brighter yellow than others; all meri each with white and red spots (red spot larger) near disto-extensor end, meri of both second pereopods and right fourth pereopod each with additional 1 or 2 red small spots on distal one third of extensor margin.

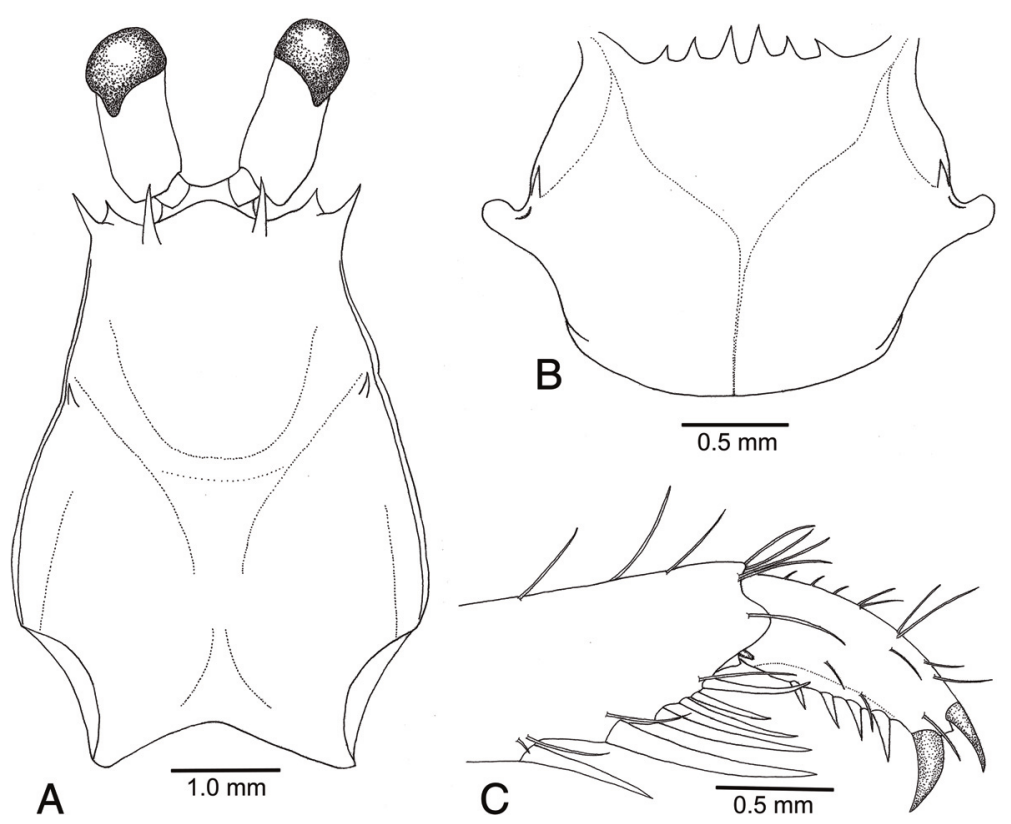

Fig. 1 Chirosty/us dolichopus Ortmann, 1892, female (CL 5.5 mm), CMNH-ZC 02495: a carapace and ocular peduncles, dorsal view; b third thoracic sternite, ventral view; c dactylus and distal part of propodus of right second pereopod, lateral view 


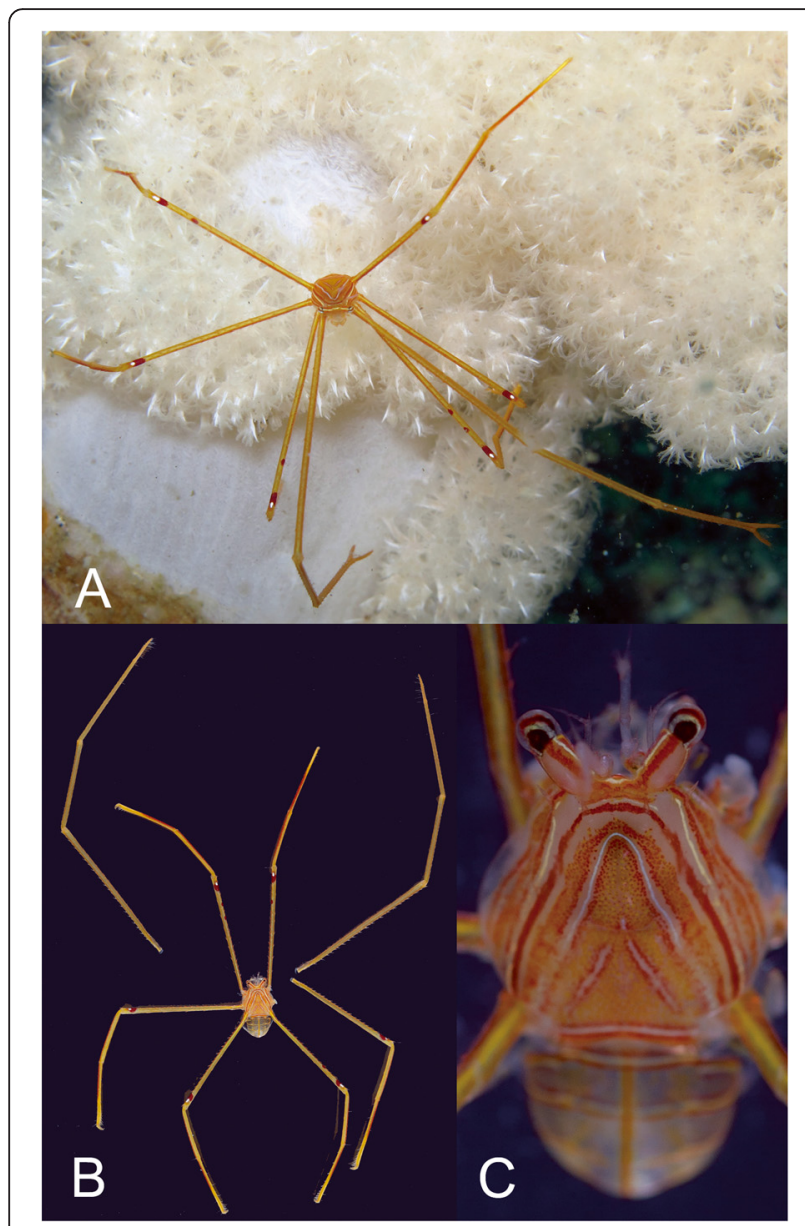

Fig. 2 Chirostylus dolichopus Ortmann, 1892, female (CL 5.5 mm), CMNH-ZC 02495: a entire specimen in situ, in association with alcyonarian soft coral at Uki-shima Islet, off Katsuyama, Boso Peninsula, Japan, 30 m; b whole body of fresh specimen, dorsal view; c carapace, abdomen and cephalic appendages of fresh specimen, dorsal view. Photographed by J. Okuno

\section{Habitat}

The present specimen was associated with an unidentified alcyonarian octocoral attached to a small rock on the sandy slope at a depth of $30 \mathrm{~m}$ (Fig. 2a). The steep slope is situated at eastern margin of the Tokyo Submarine Canyon, and reaches about $200 \mathrm{~m}$ depth over narrow horizontal distance (about $3 \mathrm{~km}$ ) (see Yano et al., 2007). At the diving sites around Uki-shima Islet, divers have observed nine other individuals referable to $C$. dolichopus during June to August of 2015, some living on colonies of fanlike gorgonaceans (Jiro Uochi, personal communication).

\section{Distribution}

Type locality: Kadsiyama (= Katsuyama), west coast of Boso Peninsula (east side of Tokyo Bay), Honshu, Japan (Ortmann, 1892). Also known from Sagami Bay (Miyake \& Baba, 1968). Other records of C. dolichopus from outside of Japan (cf. Baba et al., 2008) should be confirmed (see discussion). Known from the depths ranging 22 to 70 m (Miyake \& Baba, 1968; present study).

\section{Discussion}

The present specimen agrees quite well with the previous descriptions of C. dolichopus by Ortmann (1892), Miyake \& Baba (1968) and Baba (2005) on account of the distinguishing characters mentioned above. Baba (2005) re-examined the holotype of $C$. dolichopus and provided illustrations of selected parts of the specimen.

Baba (2009) noted that the information on colouration of C. dolichopus is available from Miyake (1960, 1982) and Takeda (1982). However, as indicated by Osawa (2007), the illustrated specimen in Miyake (1982) can be identified as C. ortmanni on account of the characteristic colour pattern, especially the presence of blackwhite-black bands on the subterminal parts of the ambulatory meri. The illustrations of $C$. dolichopus by Miyake (1960) and Takeda (1982) are unfortunately inadequate to determine the precise colouration and probably show a non-fresh specimen. Therefore, the detailed lifecolouration of $C$. dolichopus is reported here for the first time on the basis of the Japanese material.

Baba et al. (2008, Fig. 1a) showed a colour photograph of a Philippine specimen identified as C. dolichopus. However, the specimen differs from the present topotypic specimen in having the carmine-red chelipeds and ambulatory legs, and in the absence of the subterminal white and red spots on the ambulatory meri. The difference of colouration suggests that the specimen of Baba et al. (2008) may not belong to the true C. dolichopus, although re-examination of morphological characters of the specimen is required.

Furthermore, the distributional range of the true $C$. dolichopus is probably restricted in Japan and its adjacent waters in consideration of the known distributions of three shallow water congeneric species. Chirostylus ortmanni is distributed in the warm temperate waters of Japan ranging from Boso Peninsula of Honshu mainland to Satsuma Peninsula of southern Kyushu (including the Izu Islands), and northern part of Taiwan; C. sandyi has been recorded only from the Philippines and Indonesia; and $C$. stellaris is known only from the Ryukyu Islands (Osawa, 2007; Baba, 2009; Lin \& Osawa, 2014). Except for Japanese waters, $C$. dolichopus has been previously reported from Somali Republic, Mozambique Channel and Mauritious in the western Indian Ocean (Tirmizi \& Khan, 1979; Baba, 2005), Western Australia and Northern Territory in Australia (Haig, 1974; Ahyong \& Baba, 2004) and Sulu Archipelago in the Philippines (Baba, 1988); the recorded depths ranges were 35-238 $\mathrm{m}$ (Baba et al., 2008). Therefore, more detailed study is required for clarifing the systematic position of these specimens from outside of Japan. 
Ortmann (1892) described five species of squat lobsters from Japan as new to science: two chirostylids, Chirostylus dolichopus and Uroptychus japonicus Ortmann, 1892; one munidid, Munida heteracantha Ortmann, 1892; and two munidopsid, Munidopsis camelus (Ortmann, 1892) (as Galacantha A. Milne-Edwards, 1880) and M. taurulus Ortmann, 1892. As mentioned above, the type locality of C. dolichopus is Katsuyama of Boso Peninsula, Tokyo Bay. Munida heteracantha was also originally described on the basis of two specimens collected from Katsuyama and Sagami Bay, but the type locality of the species is regarded as Sagami Bay on account of the lectotype selection by Macpherson \& Baba (1993). Thus, C. dolichopus is the sole squat lobster taxon which Ortmann (1892) originaly described from Tokyo Bay.

\section{Conclusions}

The present paper describes for the first time the colouration in life of $C$. dolichopus based on a topotypic material. Our examination on the topotypic specimen revealed that C. dolichopus has a characteristic colouration in life, i. e., the brilliant yellow ground colour, the meri of the second to fourth pereopods each with white and red spots on the dorsal subterminal part, and the absence of white small spots through the entire length of the pereopods. Other shallow water congeners, such as C. ortmanni, C. sandyi, and C. stellaris, have a reddish brown ground colour and white spots on the meri of ambulatory legs (see Osawa, 2007; Baba, 2009).

\section{Abbreviations \\ SCUBA: self-contained underwater breathing apparatus; CL: postorbital carapace length; CMNH: Coastal Branch of Natural History Museum and Institute Chiba.}

\section{Acknowledgements}

We are indebted to Jiro Uochi (Kacchama Diving Survice), and Koichiro Hirashima, Takahiro Hirashima and Yasuhiro Hirashima (Kyonan-Katsuyama Fishery Association), for their help in capturing the present specimen at Ukishima Islet, off Katsuyama, Boso Peninsula, Japan. Cordial thanks are extended to Shane T. Ahyong (Australian Museum, Sydney) for kindly reviewing the manuscript and giving us valuable suggestions.

\section{Authors' contributions}

JO collected the specimen, initinally identified it, and drafted the manuscript. $\mathrm{MO}$ checked the identification of the specimen and helped to improve the final manuscript. All authors read and approved the final manuscript.

\section{Authors'information}

$\mathrm{JO}$ is a senior researcher and curator at $\mathrm{CMNH}$. MO is a researcher at the Research Center for Coastal Lagoon Environments of Shimane University.

\section{Competing interests}

The authors declare that they have no competing interests.

\section{Author details}

${ }^{1}$ Coastal Branch of Natural History Museum and Institute, 123 Yoshio, Katsuura, Chiba 299-5242, Japan. ${ }^{2}$ Research Center for Coastal Lagoon Environments, Shimane University, 1860 Nishikawatsu-cho, Matsue, Shimane 690-8504, Japan.
Received: 16 April 2016 Accepted: 21 April 2016

Published online: 12 June 2016

\section{References}

Ahyong ST, Baba K. Chirostylidae from north-western Australia (Crustacea: Decapoda: Anomura). Mem Mus Victoria. 2004;61:57-64.

Baba K. Chirostylid and galatheid crustaceans (Decapoda: Anomura) of the "Albatross" Philippine Expedition, 1907-1910. Res Crust. 1988;2(special number):1-203.

Baba K. Crustacea Decapoda: Chirostylus Ortmann, 1892, and Gastroptychus Caullery, 1896 (Chirostylidae) from New Caledonia. In: Crosnier A, editor, Résultats des Campagnes MUSORSTOM, volume 9. Mém Mus Nat Hist Nat, Paris (A). 1991; 152: 463-477. Paris: Muséum National d'Histoire Naturelle, Paris.

Baba K. Deep-sea chirostylid and galatheid crustaceans (Decapoda: Anomura) from the Indo-Pacific, with a list of species. Galathea Rep. 2005;20:5-317.

Baba K. A new species of squat lobster (Decapoda, Anomura, Chirostylidae) from the Philippines and Indonesia. Crustaceana. 2009;82:795-802.

Baba K, Macpherson E, Poore GCB, Ahyong ST, Bermudez A, Cabezas P, Lin C-W, Nizinski M, Rodrigues C, Schnabel KE. Catalogue of squat lobsters of the world (Crustacea: Decapoda: Anomura_families Chilostylidae, Galatheidae and Kiwaidae. Zootaxa. 2008:1905:1-220.

Haig J. The anomuran crabs of Western Australia: their distribution in the Indian Ocean and adjacent seas. J Mar Biol Ass India. 1974;14:443-51.

Latreille PA. Histoire naturelle, générale et particulière des Crustacés et des Insectes. Ouvrage faissant suite à l'histoire naturelle générale et particulière, composée par Leclerc de Buffon, et rédigée par C.S. Sonnini, membre de plusieurs sociétés savantes. Paris: F. DuFart; 1802.

Lin CW, Osawa M. First record of the chirostylid squat lobster, Chirostylus ortmanni Miyake \& Baba, 1968 (Cructacea: Decapoda: Anomura), from Taiwan. Platax. 2014;11:63-69.

MacLeay, WS. On the brachyurous decapod Crustacea brought from the Cape by Dr. Smith. In: Smith A. editor, Illustrations of the Annulosa of South Africa; being a portion of the objects of natural history chiefly collected during an expedition into the interior of South Africa, under the direction of Dr. Andrew Smith, in the years 1834, 1835. and 1836; fitted out by "The Cape of Good Hope Association for Exploring Central Africa". London: Smith, Elder, and Co; 1838. p. 53-71, 2 pls.

Macpherson E. Baba K. Crustacea Decapoda: Munida japonica Stimpson, 1858, and related species (Galatheidae). In: Crosnier A, editor. Résultats des Campagnes MUSORSTOM, volume 10. Mém Mus Nat Hist Nat, Paris. Paris: Muséum National d'Histoire Naturelle, Paris. 1993;156:381-420.

Milne-Edwards A. Reports on the results of dredging under the supervision of Alexander Agassiz, in the Gulf of Mexico and in the Caribbean Sea, etc. VIII. Études préliminaires sur les Crustacés. Bull Mus Comp Zool Harvard Coll. 1880;8:1-168, pls 1-2.

Miyake S. Crustacea, Decapoda, Anomura. In: Okada Y, Uchida T, editors. Encyclopedia Zoologica illustrated in colours, vol. IV. Tokyo: Hokuryukan; 1960. p. 88-97. pl. 44-48.

Miyake S. Japanese crustacean decapods and stomatopods in color: Vol. I, Macrura, Anomura and Stomatopoda. Osaka: Hoiku-sha; 1982.

Miyake S, Baba K. On the generic characters of Chirostylus, with description of two Japanese species (Crustacea, Anomura). J Fac Agr, Kyushu Univ. 1968;14:379-87.

Ortmann A. Die Decapoden-Krebse des Strasburger Museums, mit besonder Berücksichtigung der von Herrn Dr. Döderlein bei Japan und bei den Liu-KiuInslen gesammelten und zur Zeit im Strasburger Museum aufbewahrten Foren. Die Abtheilungen Galatheidea und Paguridea. Zool Jahrb. Abtheil Syst Geogr Biol Thiere. 1892;6:241-326. pls. 11-12.

Osawa M. A newspecies of Chirostylus Ortmann, 1892 (Crustacea: Decapoda: Anomura: Chirostylidae) from the Ryukyu Islands, southwestern Japan, with a supplemental description of Chirostylus ortmanni Miyake \& Baba, 1968. Zootaxa. 2007;1450:31-43.

Osawa M, Nishikiori K. A new species of the genus Chirostylus Ortmann, 1892 (Crustacea: Decapoda: Anomura: Chirostylidae) from the Ogasawara Islands, southern Japan. Proc Biol Soc Wash. 1998;111:382-388.

Takeda M. Keys to the Japanese and foreign crustaceans fully illustrated in colors. Tokyo: Hokuryukan; 1982.

Tirmizi NM, Khan B. Two species of Chirostylus from the Indian Ocean with observation on the generic characters (Decapoda, Chirostylidae). Crustaceana. 1979;5(supplement):77-88.

Yano K, Miya M, Aizawa M, Noichi T. Some aspects of the biology of the goblin shark, Mitsukurina owstoni, collected from the Tokyo Submarine Canyon and adjacent waters, Japan. Ichthyol Res. 2007;54:388-98. 